\title{
Ocean warming and acidification alter Antarctic macroalgal biochemical composition but not amphipod grazer feeding preferences
}

\author{
Julie B. Schram ${ }^{1,2, *}$, Kathryn M. Schoenrock ${ }^{1}$, James B. McClintock ${ }^{1}$, \\ Charles D. Amsler ${ }^{1}$, Robert A. Angus ${ }^{1}$ \\ ${ }^{1}$ Department of Biology, University of Alabama at Birmingham, Alabama 35294-1170 USA \\ ${ }^{2}$ Oregon Institute of Marine Biology, University of Oregon, Charleston, Oregon 97420, USA
}

\begin{abstract}
Increased anthropogenic atmospheric $\mathrm{CO}_{2}$ concentrations have resulted in ocean warming and alterations in ocean carbonate chemistry, decreasing seawater $\mathrm{pH}$ (ocean acidification). The combination of ocean warming and acidification (OWA) may alter trophic interactions in marine benthic communities along the western Antarctic Peninsula (WAP). Abundant and diverse macroalgae-grazer assemblages, dominated by macroalgae (e.g. chemically defended Desmarestia anceps and D. menziesii) and gammarid amphipods (e.g. Gondogeneia antarctica), occur on the nearshore benthos along the WAP. In the present study, the amphipod G. antarctica and macroalgae $D$. anceps and $D$. menziesii were exposed for 39 and $79 \mathrm{~d}$, respectively, to combinations of current and predicted near-future temperature $\left(1.5\right.$ and $3.5^{\circ} \mathrm{C}$, respectively) and $\mathrm{pH}(8.0$ and 7.6, respectively). Protein and lipid levels of macroalgal tissues were quantified, and 5-way choice amphipod feeding assays were performed with lyophilized macroalgal tissues collected at time zero and following exposure to the 4 temperature-pH treatments. For $D$. anceps, we found a significant interactive temperature-pH effect on lipid levels and significantly lower protein levels at reduced $\mathrm{pH}$. In contrast, tissues of $D$. menziesii exhibited significantly greater lipid levels after exposure to reduced $\mathrm{pH}$, but there was no temperature effect on lipid or protein levels. Despite shifts in macroalgal biochemical composition, there were no changes in amphipod feeding preferences. Our results indicate that despite altered macroalgal nutritional quality under OWA, both macroalgae retained their ability to deter amphipod feeding. This deterrent capacity could become an important contributor to net community resistance of macroalgae-mesograzer assemblages of the WAP to predicted OWA.
\end{abstract}

KEY WORDS: Amphipod - Antarctic ecology $\cdot$ Benthos $\cdot$ Climate change $\cdot$ Feeding selectivity Macroalgae $\cdot$ Temperature

\section{INTRODUCTION}

Large-scale ecological patterns that result from individual level organismal responses to abiotic factors have been well studied over the past century and increasingly focus on the influence of global climate change (e.g. Hoegh-Guldberg \& Bruno 2010, Gattuso et al. 2015, Gaylord et al. 2015). Since the 1750s, at-

${ }^{*}$ Corresponding author: jschram@uoregon.edu mospheric $\mathrm{CO}_{2}$ levels have increased approximately $40 \%$ and resulted in an average $\mathrm{pH}$ decline in the world's oceans of $0.1 \mathrm{pH}$ units (IPCC 2013, Gattuso et al. 2015). Ocean warming and acidification (OWA) have been associated with organism- to communitylevel impacts on marine primary producers and invertebrates and has been understudied in polar and temperate systems. The metabolic theory of ecology

(C) The authors 2017. Open Access under Creative Commons by Attribution Licence. Use, distribution and reproduction are unrestricted. Authors and original publication must be credited. 
describes the potential for fundamental individual enzyme kinematics to influence organismal metabolic rates and subsequent community interactions (Brown et al. 2004). This theoretical framework provides mechanisms by which individual responses can influence trophic interactions.

One mechanism through which primary producergrazer interactions can be mediated is through the production of feeding deterrents in the form of macroalgal secondary metabolites (reviewed by Amsler 2008, Young et al. 2015). Physical parameters such as UV radiation and desiccation, as well as biotic traits including nutrient availability, can influence the quantity and quality of secondary metabolites produced by macroalgae, as well as how predators respond to these chemical cues (Amsler 2008, Young et al. 2015). Accordingly, recent studies have assessed macroalgal production of secondary metabolites under conditions of ocean acidification (OA; e.g. Arnold et al. 2012, Schoenrock et al. 2015, Zupo et al. 2015), and herbivore (amphipod) feeding preferences for chemically defended macroalgae following grazer exposure to near-future ocean warming (Sotka \& Giddens 2009, Schram et al. 2015a) or acidification (Benítez et al. 2016, Duarte et al. 2016).

The sensitivity of macroalgae to OA is strongly influenced by phylogeny, previous exposure, and variation in length of exposure (Roleda \& Hurd 2012). For instance, filamentous turf algae with relatively short generation times exhibit higher potential for acclimation and adaptation to OA than longer-lived encrusting calcified species of algae (Roleda \& Hurd 2012). Species-specific responses to OA have also been observed in crustaceans, encompassing changes in prey sensing in crabs (e.g. de la Haye et al. 2011), patterns of distribution in amphipods near $\mathrm{CO}_{2}$ vents (e.g. Ricevuto et al. 2012), and net community composition (e.g. Alsterberg et al. 2013, Eklöf et al. 2015). Moreover, increased consumption rates of grazers (gastropods) can contribute to community level resistance to $\mathrm{OA}$ in areas of nutrient enrichment and elevated $\mathrm{CO}_{2}$, factors that significantly enhance the growth of turf algae (Falkenberg et al. 2014).

Fewer studies have investigated the combined influences of OWA on benthic grazers. In one example, feeding rates of amphipods on Sargassum spp. held at elevated temperature and reduced $\mathrm{pH}$ decreased, despite a lack of significant changes in levels of phlorotannins, the putative defensive metabolites in Sargassum spp. (Poore et al. 2013). Nonetheless, Poore et al. (2013) noted that feeding rates were influenced by the OWA conditions under which the algae were grown, rather than the OWA conditions to which the amphipods were exposed. This observation highlights the importance of understanding the role of food quality alteration when developing predictions of OWA impacts. Studies have found that ocean warming or acidification can alter the nutritional value (e.g. Xu et al. 2010, Iñiguez et al. 2016, Chen et al. 2017) or fatty acid composition of macroalgae (e.g. Rossoll et al. 2012, Bermúdez et al. 2015 Díaz-Gil et al. 2015, Cripps et al. 2016), as well as decrease their chemical or morphological feeding deterrent properties (e.g. Arnold et al. 2012, Johnson et al. 2012).

There are few geographic regions in which the impacts of climate change are more dramatic than in the Southern Ocean (Fabry et al. 2009, Ducklow et al. 2013). These impacts are particularly notable along the $1300 \mathrm{~km}$ length of the western coast of the Antarctic Peninsula (WAP) (Ducklow et al. 2013, Turner et al. 2014). Along the WAP, rapidly changing sea ice dynamics are increasing the potential for seawater absorption of atmospheric $\mathrm{CO}_{2}$ and heat (Turner et al. 2013) resulting in shifting marine landscapes (Kaiser et al. 2013, Constable et al. 2014). As a result, some models predict that within the next century, seas along the peninsula - and surrounding Antarctica more generally - will become undersaturated with respect to aragonite and calcite $(\Omega \leq 1)$ sooner than many temperate and tropical regions $(\mathrm{McNeil} \&$ Matear 2008).

Current and near-future predicted OWA impacts along the WAP emphasize the importance of gaining a better understanding of OWA effects on chemically mediated community dynamics. Amphipods are among the most abundant and diverse members of invertebrate grazer assemblages associated with the rich underwater macroalgal forests in this region (Huang et al. 2007). Estimated densities of amphipods associated with the dominant chemically defended brown macroalga Desmarestia menziesii are 308000 ind. $\mathrm{m}^{-2}$ of benthic substrate (Amsler et al. 2008). These high densities of mesograzers play an important role in regulating benthic algal growth, primarily by grazing on palatable filamentous epiphytes that occur in abundance on the largely chemically defended macroalgae (Iken 2012, Amsler et al. 2014). A previous survey of Antarctic macroalgae including $D$. menziesii and $D$. anceps evaluated whether unpalatable species were rejected by common grazers on the basis of chemical defense, morphology (thallus toughness), or nutritional quality (Amsler et al. 2005). Chemical extracts of both Desmarestia spp. were deterrent to amphipods, sea stars, and fish, but unpalatability did not appear to be 
linked to thallus toughness or nutritional quality. Puncture forces (a measure of toughness) for Desmarestia spp. did not differ from the palatable red alga Palmaria decipiens (Amsler et al. 2005), a species that the common amphipod Gondogeneia antarctica readily consumes (Aumack et al. 2010, Bucolo et al. 2011). In a survey of a wide variety of Antarctic macroalgal nutritional characteristics, no consistent pattern emerged relating algal nutritional quality to algal palatability (Amsler et al. 2005).

Previous studies have demonstrated that prominent representatives of macroalgae-mesograzer assemblages along the Antarctic Peninsula exhibit contrasting responses to chronic exposure to OWA (Schoenrock et al. 2015, Schram et al. 2016b). For example, 2 of the most conspicuous benthic canopy-forming macroalgae, $D$. menziesii and $D$. anceps, exhibited few responses when exposed to OWA, with no significant changes detected in photosynthetic parameters, overall growth, or concentrations of chlorophyll a (Schoenrock et al. 2015). The only significant change was noted in the levels of phlorotannins, which increased with exposure to reduced $\mathrm{pH}$ (Schoenrock et al. 2015). In contrast, 2 common amphipod mesograzers exhibited significant physiological responses to OWA (Schram et al. 2016b). Early exposure impacts included sub-lethal changes in physiology and compensatory feeding on a preferred alga under conditions of reduced $\mathrm{pH}$, followed over time by $>50 \%$ mortality under conditions of either reduced $\mathrm{pH}$ or a combination of reduced $\mathrm{pH}$ and elevated temperature (Schram et al. 2016b). Such varied responses indicate the potential for shifts in macroalgae-mesograzer trophic dynamics with predicted OWA.

In geographic regions supporting high densities of mesograzers, it will be essential for canopy-forming macroalgae, which fulfill similar key functional and architectural roles as kelps in temperate seas (Clayton 1994), to maintain their unpalatability to grazers under conditions of OWA. In the present study, we measured the biochemical composition in tissues of 2 common, dominant, chemically defended overstory macroalgae, $D$. anceps and $D$. menziesii, and the feeding preferences of the amphipod G. antarctica for these macroalgae, following exposure to nearfuture OWA conditions. Our aims were to (1) evaluate the potential interaction strength between these species when exposed to OWA and (2) determine whether chronic OWA exposure makes an unpalatable alga more palatable to a common generalist grazer through a reduction in the efficacy of chemical feeding deterrents or changes in biochemical compo- sition (food quality). Based on the general resistance to OWA exhibited by $D$. anceps and $D$. menziesii (Schoenrock et al. 2015) and the sensitivity of $G$. antarctica (Schram et al. 2016b), we hypothesized that amphipods would exhibit compensatory feeding of chemically defended $D$. anceps and $D$. menziesii to offset elevated metabolic demands.

\section{MATERIALS AND METHODS}

\section{Study and sample collection location}

Desmarestia anceps and D. menziesii and their associated amphipods were collected by hand with mesh bags in March 2013 (see techniques in Huang et al. 2007) using SCUBA at depths ranging from 5 to $30 \mathrm{~m}$ at 3 sites within $3.5 \mathrm{~km}$ of the US Palmer Station, Anvers Island, on the WAP $\left(64^{\circ} 46^{\prime} \mathrm{S}, 64^{\circ} 03^{\prime} \mathrm{W}\right)$. The macroalgae and amphipods were processed using the methods of Schoenrock et al. (2015) and Schram et al. (2016b). In brief, amphipods Gondogeneia antarctica were carefully sorted for similar-sized adults and were maintained in 41 plastic Nalgene bottles fitted with fine-mesh screening. The distal ends of the macroalgae were trimmed, and epibionts were gently removed using absorbent laboratory tissue. Macroalgal thalli were then labeled and weighted with a polyvinyl chloride nut. Macroalgae and amphipods were maintained separately for approximately $10 \mathrm{~d}$ in ambient seawater (temperature and $\mathrm{pH}$ ) on a $12 \mathrm{~h}$ light:12 h dark cycle before placement in the temperature-pH treatments (Schoenrock et al. 2015, Schram et al. 2016b). Immediately prior to the start of the experimental period, time zero subsamples of algal thalli, prepared as described above, were haphazardly selected and frozen at $-80^{\circ} \mathrm{C}$ for later biochemical analysis and use in feeding trials. Survival, physiological responses, and biochemical analyses of the amphipods and macroalgae investigated in the present study have previously been reported (Schoenrock et al. 2015, Schram et al. 2016b).

\section{Experimental setup}

Amphipods and macroalgal thalli $(\mathrm{n}=16$ per replicate) were haphazardly placed in shared experimental replicates. Within each replicate, amphipods were housed in smaller screened $\left(1 \mathrm{~mm}^{2}\right)$ containers with polyvinyl chloride bases to allow free water flow but prevent unmonitored interactions with $D$. anceps or 
D. menziesii housed within each replicate (see Schoenrock et al. 2015 and Schram et al. 2016b for details on containers and algal and amphipod maintenance). Amphipod health (activity level) was visually monitored in each replicate during daily fecal pellet removal. When dead amphipods or molts were discovered, they were recorded and removed immediately to maintain water quality. Over the duration of the temperature-pH exposure periods - $39 \mathrm{~d}$ for algae (midpoint samples) and $79 \mathrm{~d}$ for amphipods replicates with algae and amphipods were maintained on a $12 \mathrm{~h}$ light:12 h dark cycle at light levels similar to their natural environment (Schoenrock et al. 2015). Only midpoint macroalgal samples were included in the present study because there was insufficient tissue available at the termination of the experimental period for the feeding assays or biochemical composition analyses.

Ambient temperature and $\mathrm{pH}$ levels $\left(1.5^{\circ} \mathrm{C}\right.$ and $\mathrm{pH}$ 8.0) were selected based on annual ambient seawater temperature and $\mathrm{pH}$ conditions measured at Palmer Station on the WAP (Schram et al. 2015b). Near-future temperature and $\mathrm{pH}$ levels were selected based on estimates predicted to occur by 2100 (IPCC 2013). For this $2 \times 2$ factorial experimental design, the 4 treatment combinations ( $\mathrm{n}=12$ replicate containers per treatment) included ambient $\left(1.5^{\circ} \mathrm{C}, \mathrm{pH} 8.0\right)$, reduced $\mathrm{pH}\left(1.5^{\circ} \mathrm{C}, \mathrm{pH} 7.6\right)$, elevated temperature $\left(3.5^{\circ} \mathrm{C}, \mathrm{pH} 8.0\right)$, and combined $\left(3.5^{\circ} \mathrm{C}\right.$, $\mathrm{pH}$ 7.6) treatments. The details of instrumentation employed to regulate sea water temperature and $\mathrm{pH}$ are given in Schoenrock et al. (2015) and Schram et al. (2016b). In brief, the 48 experimental containers used in the temperature-pH experiment were divided equally among 4 temperature-controlled acrylic water tables $(113 \times 58 \times 13 \mathrm{~cm})$. Within each water table, replicates were randomly assigned to 1 of the $2 \mathrm{pH}$ treatments to avoid introducing potential artifacts attributable to the spatial arrangement (Riebesell et al. 2010). Each water table was plumbed to 1 of 4 digital water baths, which circulated a $30 \%$ glycol solution around replicates to maintain target temperatures $\left(1.5\right.$ and $\left.3.5^{\circ} \mathrm{C}\right)$. An automated AT-Control System (Aqua Medic) was used to regulate and coordinate gas delivery to the seawater within each replicate container based on continuous real time $\mathrm{pH}$ measurements. Seawater in each container was bubbled with ambient air- $\mathrm{CO}_{2}$ gas combinations to maintain appropriate $\mathrm{CO}_{2}$ enrichment for target $\mathrm{pH}$ levels. Gases were mixed on demand using a multitube gas proportioning rotameter, plumbed directly to a high-pressure aquarium air pump and a $\mathrm{CO}_{2}$ gas cylinder.

\section{Carbonate chemistry determination}

Seawater carbonate chemistry was closely monitored, and techniques are described in detail in Schram et al. (2016b). Briefly, daily seawater temperature and $\mathrm{pH}$ measurements were performed in each of the 48 experimental replicates using a solid-state $\mathrm{pH}_{\mathrm{T}}$ probe (resolution of 0.01 ; Honeywell Durafet ISFET pH probe) and a Digi-Sense ThermoLogR Thermister (Cole-Parmer) (Table 1). The $\mathrm{pH}$ probe was calibrated with certified reference material (TRIS buffer) from the Dickson Laboratory at Scripps Institute of Oceanography. Twice weekly, seawater samples were collected from each replicate for spectrophotometric analysis of $\mathrm{pH}$ and total alkalinity (TA) titrations. Spectrophotometry, using a UV/Vis spectrometer LAMBA40 (Perkin Elmer) and the $\mathrm{pH}$ sensitive dye $m$-cresol purple, was performed to determine seawater $\mathrm{pH}$ on the total hydrogen scale $\left(\mathrm{pH}_{\mathrm{T}}\right.$; Dickson et al. 2007). For TA open cell potentiometric titrations, a manual T50 open cell titrator equipped with a $\mathrm{pH}$ probe (Model DGi115-SC, Mettler-Toledo) was employed (SOP 3b; Dickson et al. 2007). At the time of seawater sample collection, temperature and salinity were recorded for carbonate chemistry calculations. Seawater spectrophotometric pH measurement and TA titration accuracy were calculated as $0.03 \mathrm{pH}$ units (mean SD, N = 11) and 4.02 $\mu \mathrm{mol} \mathrm{kg} \mathrm{kW}^{-1} \mathrm{SW}, \mathrm{N}=17$ ) based on repeated measurements of seawater certified reference material from the Dickson Lab. Salinity was determined with either a Model 3200 conductivity instrument (YSI) with conductivity cell (3253 Model B, YSI) or refractometer (1.000-1.070 specific gravity, Model A366ATC, Vista). We used $\mathrm{CO}_{2}$ constants from Roy et al. (1993) and a $\mathrm{KHSO}_{4}$ acidity constant from Dickson (1990) for carbonate chemistry calculations (Table 2). All seawater chemistry measurements are available on the National Science Foundation Antarctic Master Directory (www.usap-data.org/entry/NSF-ANT10-41022/201607-06_09-49-03/).

Table 1. Daily mean $( \pm \mathrm{SD}) \mathrm{pH}_{\mathrm{T}}$ near Anvers Island, western Antarctic Peninsula (in situ), and in experimental treatments representing present day ambient $\left(1.5^{\circ} \mathrm{C}, \mathrm{pH} 8.0\right)$, reduced $\mathrm{pH}\left(1.5^{\circ} \mathrm{C}\right.$, pH 7.6), elevated temperature $\left(3.5^{\circ} \mathrm{C}, \mathrm{pH} 8.0\right)$, or combined $\left(3.5^{\circ} \mathrm{C}, \mathrm{pH} 7.6\right)$ seawater conditions

\begin{tabular}{|lcc|}
\hline & $\mathrm{pH}_{\mathrm{T}}$ & Temp $\left({ }^{\circ} \mathrm{C}\right)$ \\
\hline In situ & $8.02 \pm 0.04$ & $0.29 \pm 0.79$ \\
Ambient & $8.07 \pm 0.09$ & $1.51 \pm 0.27$ \\
Reduced $\mathrm{pH}$ & $7.59 \pm 0.16$ & $1.49 \pm 0.27$ \\
Elevated temperature & $8.05 \pm 0.05$ & $3.52 \pm 0.35$ \\
Combined & $7.58 \pm 0.25$ & $3.52 \pm 0.30$ \\
\hline
\end{tabular}


Table 2. Seawater chemistry parameters (mean \pm SD) near Anvers Island, western Antarctic Peninsula (in situ), and in microcosm treatments representing present day ambient $\left(1.5^{\circ} \mathrm{C}, \mathrm{pH} 8.0\right)$, reduced $\mathrm{pH}\left(1.5^{\circ} \mathrm{C}, \mathrm{pH} 7.6\right)$, elevated temperature $\left(3.5^{\circ} \mathrm{C}, \mathrm{pH} 8.0\right)$, or combined $\left(3.5^{\circ} \mathrm{C}, \mathrm{pH} 7.6\right)$ seawater conditions, calculated from spectrophotometric $\mathrm{pH}_{\mathrm{T}}$, total alkalinity (TA), temperature (temp), and salinity. DIC: dissolved inorganic carbon, $\Omega_{\text {arg }}$ : aragonite saturation state, $\Omega_{\text {cal }}$ : calcite saturation state

\begin{tabular}{|lcccccccc}
\hline & $\mathrm{pH}_{\mathrm{T}}$ & $\begin{array}{c}\mathrm{TA} \\
\left(\mu \mathrm{mol} \mathrm{kg}{ }^{-1} \mathrm{SW}\right)\end{array}$ & $\begin{array}{c}\mathrm{Temp} \\
\left({ }^{\circ} \mathrm{C}\right)\end{array}$ & Salinity & $\begin{array}{c}p \mathrm{CO}_{2} \\
(\mu \mathrm{atm})\end{array}$ & $\begin{array}{c}\mathrm{DIC} \\
\left(\mu \mathrm{mol} \mathrm{kg}{ }^{-1} \mathrm{SW}\right)\end{array}$ & $\Omega_{\text {arg }}$ & $\Omega_{\mathrm{cal}}$ \\
\hline In situ & $8.10 \pm 0.03$ & $2283 \pm 36$ & $0.91 \pm 0.72$ & $35.6 \pm 0.6$ & $327 \pm 28$ & $2132 \pm 43$ & $1.67 \pm 0.12$ & $2.66 \pm 0.19$ \\
Ambient & $8.05 \pm 0.14$ & $2268 \pm 60$ & $1.45 \pm 0.30$ & $35.8 \pm 0.78$ & $409 \pm 290$ & $2133 \pm 71$ & $1.55 \pm 0.32$ & $2.46 \pm 0.51$ \\
Reduced pH & $7.55 \pm 0.18$ & $2292 \pm 55$ & $1.46 \pm 0.57$ & $35.7 \pm 0.63$ & $1407 \pm 583$ & $2316 \pm 82$ & $0.57 \pm 0.25$ & $0.91 \pm 0.40$ \\
Elevated temperature & $8.05 \pm 0.10$ & $2271 \pm 56$ & $3.19 \pm 0.78$ & $35.8 \pm 0.6$ & $393 \pm 127$ & $2125 \pm 54$ & $1.66 \pm 0.29$ & $2.63 \pm 0.47$ \\
Combined & $7.55 \pm 0.17$ & $2294 \pm 36$ & $3.32 \pm 0.98$ & $35.7 \pm 0.56$ & $1433 \pm 531$ & $2311 \pm 67$ & $0.61 \pm 0.26$ & $0.96 \pm 0.41$ \\
\hline
\end{tabular}

\section{Macroalgal biochemical composition}

Time zero subsamples and subsamples of D. anceps and $D$. menziesii from individuals held in each temperature-pH treatment for $39 \mathrm{~d}$ were lyophilized and utilized for measurements of soluble protein and total nonpolar lipid levels. Soluble protein and total nonpolar lipid extractions were performed as described by Schram et al. (2016b). In short, tissues used for soluble protein determinations were weighed to the nearest $0.1 \mathrm{mg}$ and extracted in $5 \mathrm{ml}$ of $1 \mathrm{M} \mathrm{NaOH}$ for $24 \mathrm{~h}$. After extraction, aliquots of $5 \mu \mathrm{l}$ of each solution were added to Bradford Dye Reagent (Bio-Rad) and analyzed in triplicate on a microplate spectrophotometer (BioTek Instruments; Bradford 1976). The $\mu \mathrm{g}$ protein $\mathrm{mg}^{-1}$ dry tissue was then calculated based on protein concentrations of extract solutions and the dry tissue weight of each sample extracted. Due to variations in growth and prioritized sampling for phlorotannin concentration, there were uneven amounts of tissue available for protein analysis. The sample sizes for $D$. anceps maintained in ambient $(\mathrm{n}=9)$, reduced $\mathrm{pH}(\mathrm{n}=9)$, elevated temperature $(n=11)$, and combined $(n=10)$ conditions were lower than for $D$. menziesii $(\mathrm{n}=12$, $11,12,12$, respectively).

Levels of nonpolar lipids (\% dry weight) were determined for macroalgae using a technique based on that developed by Folch et al. (1957). Tissues were weighed to the nearest $0.01 \mathrm{~g}$ and extracted in $25 \mathrm{ml}$ of a 2:1 chloroform:methanol solution. Solvent solutions were then filtered, and $4 \mathrm{ml}$ of $0.9 \% \mathrm{NaCl}$ was added. Solutions were thoroughly mixed, centrifuged, and then the lower chloroform-solvent solution containing the nonpolar lipid fraction was removed and evaporated. Lipids were then re-suspended in chloroform, transferred to pre-weighed shell vials, and the remaining solvent was evaporated. Total nonpolar lipid content was determined gravimetrically as the percent mass of the total amount of dry tissue ex- tracted. Due to variations in growth, there were uneven amounts of tissue available for lipid analysis. The sample sizes for $D$. anceps maintained in ambient $(n=9)$, reduced $\mathrm{pH}(\mathrm{n}=8)$, elevated temperature $(\mathrm{n}=$ $8)$, and combined $(n=8)$ conditions were lower than for $D$. menziesii ( $=12,11,12,12$, respectively).

The nonpolar lipid content (\% dry wt) was graphed as a function of soluble protein content (\% dry wt) to synthesize how changes in each component contributed to the net biochemical composition of $D$. anceps and $D$. menziesii held in the 4 temperature$\mathrm{pH}$ treatments. Macroalgal biochemical composition was compared using a 2-way ANOVA in JMP (v.12.0.1, SAS Institute) to determine whether exposure to the temperature-pH treatments influenced tissue composition. Separate ANOVAs were run for soluble protein and nonpolar lipid content for each macroalga. Results were considered significant at $\mathrm{p} \leq 0.05$ for all data analyses in the present study.

\section{Feeding assays}

Amphipod feeding trials commenced immediately following the $79 \mathrm{~d}$ exposure to experimental treatments. New growth of algal thalli was trimmed following the $39 \mathrm{~d}$ exposure period for use in feeding trials, gently blotted with laboratory tissue, frozen at $-80^{\circ} \mathrm{C}$, and then lyophilized. We used lyophilized tissue imbedded in food disks rather than pieces of fresh thallus tissue to focus on the role of macroalgal biochemical composition and chemical feeding deterrents by removing the potential bias of tissue toughness or algal shape on amphipod feeding choices. Based on the results of previous studies, we anticipated that $G$. antarctica would not consume unmanipulated, field-collected $D$. anceps or D. menziesii if these were presented as fresh thallus material instead of ground freeze-dried tissue in artificial food disks (Huang et al. 2006, Amsler et al. 2009). 
Artificial food disks were prepared following the general procedures outlined by Amsler et al. (2005) and Huang et al. (2006). Briefly, lyophilized tissues from $D$. anceps and $D$. menziesii were ground to a fine, homogenous powder using a ceramic mortar and pestle. Artificial food disks were prepared from a $1.8 \%$ alginate solution and contained $5 \%$ macroalgal tissue. Food disks prepared from D. anceps and $D$. menziesii were color-coded for reference (based on whether they were collected at time zero or from 1 of the 4 temperature-pH treatments) by adding 1 drop of colored food dye. Prior to this experiment, we confirmed that alginate foods containing colored food dye did not alter feeding activity of $G$. antarctica. The alga-alginate-dye slurry was mixed thoroughly and then gelatinized by adding cold $1 \mathrm{M}$ calcium chloride $\left(\mathrm{CaCl}_{2}\right)$ in petri dishes. Petri dishes containing gelatinized ground algal tissues were held at $4^{\circ} \mathrm{C}$ for $24 \mathrm{~h}$ before food disks were cut out with a $2 \mathrm{~mm}$ diameter cork borer. Food disks were prepared both for use in 5-way choice feeding assays and for simultaneous paired autogenic control assays, to account for changes in disk wet weight due to seawater exposure alone (e.g. Peterson \& Renaud 1989, Prince et al. 2004). Algal food disks were haphazardly assigned to amphipod compartments in temperature-pH treatment replicates, in which amphipods were maintained for the duration of the experimental period. Paired autogenic control disks were subsequently placed in empty compartments of the same temperature-pH replicate, which formerly held $D$. anceps or D. menziesii, at the beginning of each feeding choice assay. Paired food disks were removed at the same time at the completion of each assay.

Immediately before placing food disks into compartments of replicates containing $G$. antarctica ( $\mathrm{n}=$ 1-16, depending on survival in a given replicate container after 79 d exposure) or empty compartments, each experimental and autogenic control food disk was carefully blotted on laboratory tissue for $10 \mathrm{~s}$ and weighed wet (mg) on a top-loading balance (PM4600, Mettler Toledo). Two rounds of feeding trials were performed in the present study: the first tested disks containing tissues of $D$. anceps and the second those with tissues of D. menziesii. Each 5-way choice feeding trial lasted until approximately half of at least 1 of the 5 food disks was consumed in a given replicate.

Consumption rates $\left(\mathrm{mg} \mathrm{h}^{-1}\right.$ amphipod $^{-1}$ ) for each food disk presented to amphipods were calculated as described by Schram et al. (2015a). To test whether mean consumption rates in each treatment were greater than zero, we used 1-tailed 1-sample $t$-tests. Because of the large number of tests performed (20 per species), we acknowledge that, without using a Type I error correction procedure, approximately $5 \%$ of 'significant' results may be Type I errors. In order to ensure that the Type I error rate does not exceed $5 \%$ over all tests performed for each species, we used the sequential Bonferroni procedure which adjusts the critical value needed for significance for each test. Unfortunately, although these procedures ensure that the experiment Type I error rate does not exceed 0.05, they also reduce the power of the tests. For that reason, their use has been questioned (e.g. Rothman 1990, Moran 2003, Nakagawa 2004). Test results which would be deemed significant without using the sequential Bonferroni procedure $(p<0.05)$ can be seen by observing the calculated p-value for each test.

To identify the influence of temperature and $\mathrm{pH}$ on amphipod preferential consumption of macroalgae maintained in each temperature-pH treatment, we transformed the 5 consumption rate values $\left(\mathrm{mg} \mathrm{h}^{-1}\right.$ amphipod $^{-1}$ for each food disk presented) for each replicate into 4 values by subtracting the consumption rates for the time zero food disks in a given replicate $\left(c_{0}\right.$, made from the untreated algae) from the consumption rates for each of the other macroalgae maintained in each temperature-pH treatment $\left(c_{\mathrm{t}}\right.$, Eq. 1) as proposed by Manly (1993) to allow for the inclusion of sampling error in mean consumption estimates. This transformation resulted in corrected consumption rates $\left(C_{\mathrm{c}}\right)$ :

$$
C_{\mathrm{C}}=C_{\mathrm{t}}-C_{0}
$$

Corrected consumption rates $\left(\mathrm{mg} \mathrm{h}^{-1}\right.$ amphipod $^{-1}$ ) were subsequently compared for amphipods maintained in each temperature-pH treatment using a multivariate Hotelling's $T^{2}$ test on the transformed values in SAS (SAS Institute; Prince et al. 2004). For this analysis, results were considered significant at $\mathrm{p} \leq 0.05$. By using this multivariate approach, we were able to directly compare the consumption rates of the amphipods based on their temperature or $\mathrm{pH}$ exposure for all of the algae they were presented. This approach is necessary, because recorded consumption rates for each alga within a given replicate are not independent measures. Due to decreased survival in reduced $\mathrm{pH}$ treatments following the $79 \mathrm{~d}$ exposure period (Schram et al. 2016b), feeding assays were performed with amphipods maintained in 31 of the original 48 replicates (ambient $\mathrm{n}=12$, reduced $\mathrm{pH} n=7$, elevated temperature $n=12$, combined $n=8$ ). 


\section{RESULTS}

\section{Macroalgal biochemical composition}

The biochemical percent composition of the tissues of both Desmarestia anceps and D. menziesii were significantly altered under various experimental conditions of temperature and $\mathrm{pH}$ over the $39 \mathrm{~d}$ exposure period (Table 3). Protein content of the tissues of $D$. anceps was significantly lower in the elevated temperature treatment, and there was a significant interactive effect of temperature and $\mathrm{pH}$ on the percentage of lipids present (Fig. 1a, Table 3). Lipid content was highest in the ambient treatment and lowest in the elevated temperature treatment (Fig. 1a). Temperature and $\mathrm{pH}$ exhibited an antagonistic effect on lipid levels, resulting in a smaller reduction in \% lipid than when exposed to elevated temperature alone (Fig. 1a). In contrast, the tissues of D. menziesii exhibited a significantly greater lipid content following the exposure period, but reduced $\mathrm{pH}$ caused no significant change in \% protein (Fig. 1b, Table 3). There were no significant interactive temperature-pH effects on either the protein or lipid levels in $D$. menziesii tissues (Fig. 1b, Table 3).

\section{Feeding assays}

Despite very low consumption rates, several of the mean consumption rates per amphipod were significantly greater than zero in each amphipod exposure treatment (Table 4). Amphipods exhibited a nonsignificant tendency to consume more food containing tissues of both macroalgae investigated following exposure to the combined treatment (Fig. 2). There were no significant differences in amphipod corrected consumption rates based either on amphipod or algal temperature-pH treatment for either Desmarestia spp. (Fig. 2, Table 5). There also were no significant differences in the amphipod corrected consumption rates due to temperature-pH interaction for either Desmarestia spp. maintained in the 4 experimental temperature-pH treatments (Fig. 2, Table 5).

\section{DISCUSSION}

In the present study, we demonstrate that the biochemical composition of the thallus tissues of 2 ecologically dominant brown macroalgae, Desmarestia anceps and D. menziesii, are altered by chronic exposure to OWA. Schoenrock et al. (2015) established
Table 3. Two-way ANOVA results for comparisons of protein and lipid content of Desmarestia anceps and D. menziesii tissue following exposure to 4 temperature- $\mathrm{pH}$ treatments for $39 \mathrm{~d}$. * Significant treatment effects ( $\mathrm{p} \leq 0.05)$

\begin{tabular}{|llcccc|}
\hline Trait & Source & df & MS & $F$ & $\mathrm{p}$ \\
\hline $\begin{array}{l}\text { D. anceps } \\
\text { \% protein }\end{array}$ & Temp & 1,35 & 10.74 & 1.97 & 0.17 \\
& pH & 1,35 & 29.14 & 5.33 & $0.03^{*}$ \\
& Temp $\times \mathrm{pH}$ & 1,35 & 12.65 & 2.31 & 0.14 \\
\% lipid & Temp & 1,29 & 0.04 & 0.11 & 0.74 \\
& pH & 1,29 & 2.65 & 7.92 & $0.01^{*}$ \\
& Temp $\times \mathrm{pH}$ & 1,29 & 1.52 & 4.55 & $0.04^{*}$ \\
D. menziesii & & & & & \\
\% protein & Temp & 1,43 & 0.14 & 0.10 & 0.75 \\
& pH & 1,43 & 0.06 & 0.05 & 0.83 \\
\% lipid & Temp $\times \mathrm{pH}$ & 1,43 & 0.04 & 0.03 & 0.87 \\
& Temp & 1,43 & 0.20 & 14.81 & $<0.001^{*}$ \\
& pH & 1,43 & 0.01 & 0.71 & 0.41 \\
& Temp $\times \mathrm{pH}$ & 1,43 & 0.002 & 0.16 & 0.69 \\
\hline
\end{tabular}
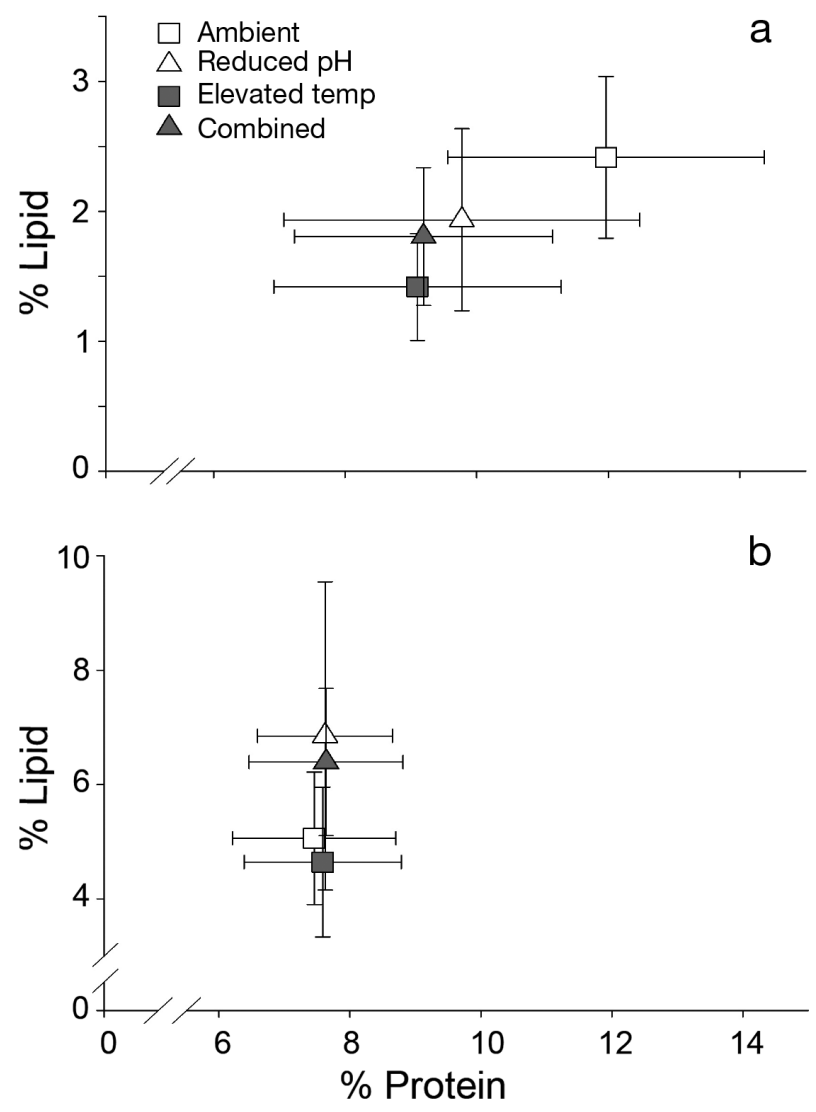

Fig. 1. Macroalgal biochemical composition representing mean $( \pm \mathrm{SE}) \%$ protein and lipid of the tissues of the brown macroalgae (a) Desmarestia anceps $(\mathrm{n}=9-11)$ and (b) Desmarestia menziesii $(\mathrm{n}=11-12)$ following a $39 \mathrm{~d}$ exposure to ambient $\left(1.5^{\circ} \mathrm{C}, \mathrm{pH} 8.0\right)$, reduced $\mathrm{pH}\left(1.5^{\circ} \mathrm{C}, \mathrm{pH} 7.6\right)$, elevated temperature $\left(3.5^{\circ} \mathrm{C}, \mathrm{pH} 8.0\right)$, or combined $\left(3.5^{\circ} \mathrm{C}\right.$, $\mathrm{pH}$ 7.6) seawater conditions 
Table 4. Results of 1-tailed 1-sample t-tests for amphipod consumption rates of Desmarestia anceps and D. menziesii used in 5way choice assays following the $79 \mathrm{~d}$ amphipod exposure period. Amphipod and algal treatments represented present day ambient $\left(1.5^{\circ} \mathrm{C}, \mathrm{pH} 8.0\right)$, reduced $\mathrm{pH}\left(1.5^{\circ} \mathrm{C}, \mathrm{pH} 7.6\right)$, elevated temperature $\left(3.5^{\circ} \mathrm{C}, \mathrm{pH}\right.$ 8.0), or combined $\left(3.5^{\circ} \mathrm{C}, \mathrm{pH} 7.6\right)$ seawater conditions, with an additional algal treatment representing baseline tissue (time zero). ${ }^{*}$ Consumption rates in these treatment combinations were significantly greater than zero based on sequential Bonferroni corrections

\begin{tabular}{|c|c|c|c|c|c|c|c|c|c|c|c|c|}
\hline \multirow[t]{3}{*}{ Algal treatments } & \multicolumn{12}{|c|}{-Amphipod treatments - } \\
\hline & \multicolumn{3}{|c|}{ Ambient } & \multicolumn{3}{|c|}{ Elevated temperature } & \multicolumn{3}{|c|}{ Reduced pH } & \multicolumn{3}{|c|}{ Combined } \\
\hline & $t$ & df & $\mathrm{p}$ & $t$ & $\mathrm{df}$ & $\mathrm{p}$ & $t$ & df & $\mathrm{p}$ & $t$ & df & $\mathrm{p}$ \\
\hline \multicolumn{13}{|l|}{ D. anceps } \\
\hline Time zero & 2.22 & 11 & 0.02 & 3.41 & 11 & 0.003 & 1.49 & 6 & 0.09 & 1.22 & 7 & 0.13 \\
\hline Ambient & 2.65 & 11 & 0.01 & 3.31 & 11 & 0.003 & 2.08 & 6 & 0.04 & 2.97 & 7 & 0.01 \\
\hline Reduced pH & 3.25 & 11 & 0.004 & 3.12 & 11 & 0.005 & 1.91 & 6 & 0.05 & 2.94 & 7 & 0.01 \\
\hline Elevated temperature & 3.99 & 11 & $<0.001^{*}$ & 3.08 & 11 & 0.005 & 5.57 & 6 & $<0.001^{*}$ & 2.32 & 7 & 0.03 \\
\hline Combined & 2.21 & 11 & 0.02 & 3.74 & 11 & $0.002^{*}$ & 2.01 & 6 & 0.05 & 3.20 & 7 & 0.008 \\
\hline \multicolumn{13}{|l|}{ D. menziesii } \\
\hline Time zero & 2.57 & 11 & 0.01 & 2.27 & 11 & 0.02 & 1.60 & 6 & 0.08 & 3.12 & 7 & 0.008 \\
\hline Ambient & 4.35 & 11 & $<0.001^{*}$ & 1.87 & 11 & 0.04 & 1.45 & 6 & 0.10 & 1.48 & 7 & 0.09 \\
\hline Reduced pH & 4.43 & 11 & $<0.001^{*}$ & 0.63 & 11 & 0.27 & 1.53 & 6 & 0.09 & 0.35 & 7 & 0.37 \\
\hline Elevated temperature & 3.50 & 11 & $0.002^{*}$ & 1.52 & 11 & 0.08 & 1.89 & 6 & 0.05 & 1.93 & 7 & 0.05 \\
\hline Combined & 5.74 & 11 & $<0.001^{*}$ & 4.10 & 11 & $<0.001^{*}$ & 1.90 & 6 & 0.05 & 2.35 & 7 & 0.03 \\
\hline
\end{tabular}
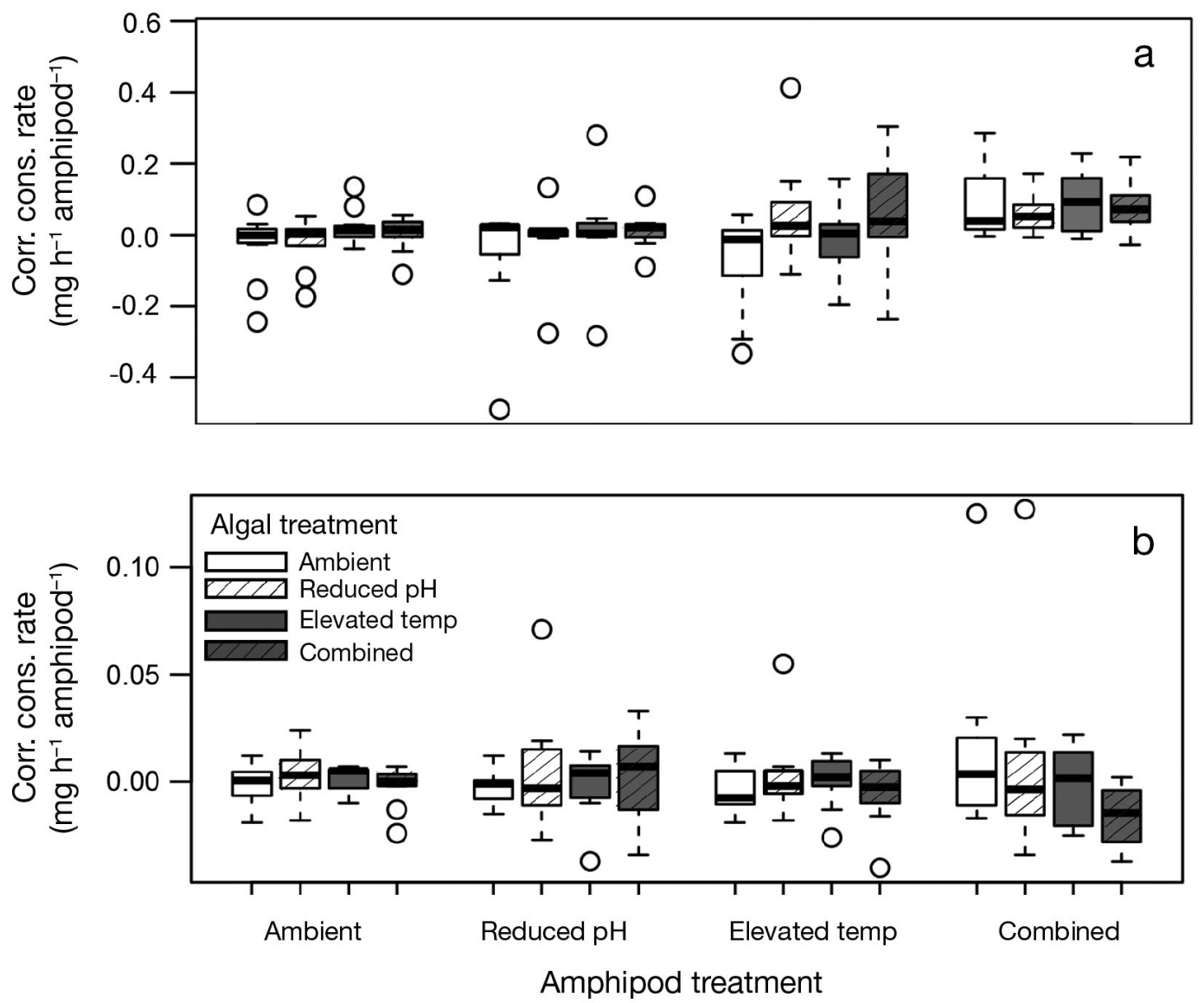

Fig. 2. Corrected amphipod consumption rates $\left(\mathrm{mg} \mathrm{h}^{-1} \mathrm{amphipod}^{-1}\right.$; mean $\left.\pm \mathrm{SE}\right)$ for the brown macroalgae (a) Desmarestia anceps and (b) D. menziesii following exposure to temperature-pH treatments representing ambient $\left(1.5^{\circ} \mathrm{C}, \mathrm{pH} 8.0\right)$, reduced $\mathrm{pH}$ $\left(1.5^{\circ} \mathrm{C}, \mathrm{pH} 7.6\right)$, elevated temperature $\left(3.5^{\circ} \mathrm{C}, \mathrm{pH} 8.0\right)$, or combined $\left(3.5^{\circ} \mathrm{C}, \mathrm{pH} 7.6\right)$ seawater conditions. Solid horizontal lines: median, boxes: 25th and 75th percentiles, whiskers: full range, open circles: outliers. There were no significant differences in 
Table 5. Results of Hotelling's $T^{2}$ analysis of corrected consumption rates of the amphipod Gondogeneia antarctica for Desmarestia anceps and $D$. menziesii following the $79 \mathrm{~d}$ amphipod exposure period. Because there were no significant temperature or $\mathrm{pH}$ effects on amphipod consumption, we did not perform post hoc analyses

\begin{tabular}{|c|c|c|c|c|c|}
\hline Macroalgal species & Source & df & $T^{2}$ & $F$ & $\mathrm{p}$ \\
\hline \multirow{3}{*}{ Amphipods presented with treated $D$. anceps choices } & Temp & 4,32 & 1.95 & 1.42 & 0.25 \\
\hline & $\mathrm{pH}$ & 4,32 & 1.03 & 0.75 & 0.56 \\
\hline & Temp $\times \mathrm{pH}$ & 4,32 & 2.35 & 1.71 & 0.17 \\
\hline \multirow[t]{3}{*}{ Amphipods presented with treated $D$. menziesii choices } & Temp & 4,32 & 2.41 & 1.75 & 0.16 \\
\hline & $\mathrm{pH}$ & 4,32 & 1.88 & 1.37 & 0.27 \\
\hline & Temp $\times \mathrm{pH}$ & 4,32 & 2.27 & 1.65 & 0.19 \\
\hline
\end{tabular}

that the physiological performance of these algal species did not respond negatively to the same levels of warming and acidification as used in the present study. Macroalgal tissues used in the present experiment were removed at the midpoint measurement, at which time individual algae were growing rapidly with the greatest amount of growth in the elevated temperature treatments yet with few differences in photosynthetic parameters (Schoenrock et al. 2015). Despite this greater growth, we found that the tissues of $D$. anceps in the elevated temperature treatments contained the same amount of protein and slightly more lipid than those in the combined (elevated temperature and reduced $\mathrm{pH}$ ) treatment, suggesting that $D$. anceps is able to maintain comparable tissue composition at higher growth rates. Individuals of $D$. anceps and D. menziesii maintained in ambient and reduced $\mathrm{pH}$ treatments exhibited similar growth (Schoenrock et al. 2015). However, the tissues of $D$. anceps in the reduced $\mathrm{pH}$ treatment contained significantly lower protein levels than those in the ambient treatment. These levels indicate that even though the $D$. anceps in the reduced $\mathrm{pH}$ treatment maintained their growth rates, there may have been a cost of maintaining growth, resulting in lower protein levels. In contrast, D. menziesii- which exhibited comparable growth at reduced $\mathrm{pH}$ - maintained greater lipid levels than individuals with the same growth rates in the ambient treatment, indicating a potential benefit of reduced $\mathrm{pH}$. Despite the significant changes in biochemical composition that we detected over the exposure period, levels of biochemical constituents remained within the bounds of previously documented seasonal changes in protein and lipid for $D$. anceps and D. menziesii (Peters et al. 2005).

There has long been debate about the role of phlorotannins, but there is general agreement that they can play important roles in macroalgal cellular structure and chemical ecology (Amsler \& Fairhead 2006). Previous studies with purified phlorotannins have shown that those from $D$. anceps deter feeding of G. antarctica, but that this is not true for phlorotannins from $D$. menziesii, at least as present in freshly collected algae (Fairhead et al. 2006, Iken et al. 2009). This finding is consistent with crude extract bioassays showing that amphipod feeding deterrence is significant for crude lipophilic extracts of $D$. menziesii and crude hydrophilic extracts of $D$. anceps (Amsler et al. 2005). When $D$. anceps and $D$. menziesii were maintained in experimental temperature and $\mathrm{pH}$ treatments for $79 \mathrm{~d}$, both had significantly greater levels of phlorotannins in all temperature and $\mathrm{pH}$ treatments than those measured at the onset of the experiment (Schoenrock et al. 2015). Only individuals of D. menziesii held in the reduced $\mathrm{pH}$ treatment had significantly greater levels of phlorotannins when compared with all other temperature-pH treatments (Schoenrock et al. 2015). Of the 2 macroalgae examined in the present study, D. menziesii generally occurs at shallower depths than $D$. anceps. It is possible that over the course of the exposure period, this shallower species was better equipped to up- or down-regulate the phlorotannin production as needed (Schoenrock et al. 2015). Despite this greater lability and the ability of phlorotannins to serve as feeding deterrents in $D$. anceps, we observed very low amphipod consumption rates in the present study, but the rates were higher for $D$. anceps than for $D$. menziesii.

In a previous study with the amphipod G. antarctica, we found that feeding preferences of this generalist amphipod species could be altered by a brief acute $(24 \mathrm{~h})$ exposure to elevated seawater temperature (Schram et al. 2015a). However, in that study, feeding preferences were altered only for weakly chemically defended macroalgae and brief exposure to elevated temperature. In the present study, we measured feeding preferences for macroalgae known to produce stronger feeding deterrents (Amsler et al. 2005) following a 3 mo exposure to combinations of OWA and found no change in feeding preferences. 
Additional sublethal results of this longer exposure of the $G$. antarctica investigated in the present study to OWA included reduced levels of survival likely linked with stress associated with molting, increased consumption rates for the preferred macroalga Palmaria decipiens, and no change in whole body protein content (Schram et al. 2016b). Based on the potential for physiological stress with elevated temperature and reduced $\mathrm{pH}$, we anticipated some mortality, but also the potential for compensatory feeding (Cruz-Rivera \& Hay 2003) despite the feeding deterrent properties of the 2 species of macroalgae tested in the present study (Iken 2012, Amsler et al. 2014).

Compensatory feeding - the capacity to consume greater quantities of a given food to compensate for lower food quality - has been demonstrated in amphipods (e.g. Cruz-Rivera \& Hay 2001). For example, Duarte et al. (2016) exposed the temperate amphipod Orchestoidea tuberculata to chronic reduced $\mathrm{pH}$ over a period of $10 \mathrm{~d}$ and detected a compensatory feeding response. In the present study, we observed a small degree of compensatory feeding in G. antarctica for food disks containing tissues of $D$. anceps which had reduced food quality (lower levels of lipids) when compared to those of $D$. menziesii. However, such a minor degree of compensatory feeding as observed in the present study would be unlikely to result in a measurable change in the net interaction strength between these 2 macroalgae and its common sympatric grazer.

Our results contrast with a recent study by Poore et al. (2016), who examined the palatability of 6 macroalgal species maintained under combinations of elevated temperature and reduced $\mathrm{pH}$ for $2 \mathrm{wk}$ and detected significant changes in palatability to the gastropod Phasianotrochus eximius. Subtle changes in feeding preferences following exposure to combinations of OWA have also been observed in the amphipod P. parmerong (Poore et al. 2013): feeding rates of $P$. parmerong did not change based on its exposure to elevated temperature and reduced $\mathrm{pH}$, but were rather influenced by an interaction between the effect of $\mathrm{pH}$ on its macroalgal food and the effect of temperature on its own physiology. This result indicates that algal food quality and grazer exposure to near-future environmental conditions can interact to affect the net strength of consumer-prey interactions (Poore et al. 2013). In contrast, an unaltered interaction between predator and prey, despite individual responses to OWA over a 5 mo exposure, has been observed in the predatory green crab Carcinus maenas and its common prey, the periwinkle Littorina littorea (Landes \& Zimmer 2012). In the present study, we similarly observed unaltered net macroalgae-grazer interactions. Interaction strength was maintained because the chemical defenses in both Desmarestia species were sufficient to prevent a shift in interaction strength despite significant changes in macroalgal tissue quality. At the community level, this prevention is likely to contribute to net assemblage resistance.

Resistance to a disturbance can be defined as the capacity of a system to absorb the impacts of a disturbance without changing (reviewed by Pimm 1984, Folke et al. 2004). Resistance to long-term environmental disturbances, such as climate change, may play an important role in maintaining ecosystem function due to the associated unknown recovery period (Côté \& Darling 2010). Other mechanisms that contribute to community-level resistance to the environmental challenges that accompany climate change include response diversity (e.g. Schram et al. 2016a) and trophic compensation (e.g. Falkenberg et al. 2012, 2013, 2014, Ghedini et al. 2015). The resistance of macroalgae to OWA in the present study maintained an unaltered interaction with a prominent grazer in the crustacean grazer assemblages associated with the ecologically dominant brown algae $D$. anceps and $D$. menziesii, despite grazer sensitivity to experimental temperature and $\mathrm{pH}$ treatments (Schram et al. 2016b). This finding is important given the remarkably high densities of macroalgae and their associated grazers in coastal habitats of the WAP. Algal communities in geographic regions comprising less chemically defended species, however, may be less resistant to near-future seawater warming and acidification, thus increasing the potential for an ecological regime shift.

Acknowledgements. The authors gratefully acknowledge the exemplary logistical and science support of the staff of Antarctic Support Contract. Margaret Amsler and Kevin Scriber of the Department of Biology at UAB provided valuable field assistance, and Charles Katholi of the UAB Department of Biostatistics provided invaluable statistics consultation. Additional thanks are due to Kenan Matterson for his assistance with protein assays and Robert Thacker for access to his laboratory equipment. The present study was supported by NSF award ANT-041022 (J.B.M., C.D.A., R.A.A.) from the Antarctic Organisms and Ecosystems program. J.B.M. acknowledges support from an Endowed Professorship in Polar and Marine Biology from UAB.

\section{LITERATURE CITED}

Alsterberg C, Eklöf JS, Gamfeldt L, Havenhand JN, Sundbäck K (2013) Consumers mediate the effects of experimental ocean acidification and warming on primary producers. Proc Natl Acad Sci USA 110:8603-8608

Amsler CD (ed) (2008) Algal chemical ecology. Springer, Berlin 
Amsler CD, Fairhead VA (2006) Defensive and sensory chemical ecology of brown algae. Adv Bot Res 43:1-91

Amsler CD, Iken K, McClintock JB, Amsler MO and others (2005) Comprehensive evaluation of the palatability and chemical defenses of subtidal macroalgae from the Antarctic Peninsula. Mar Ecol Prog Ser 294:141-159

Amsler CD, McClintock JB, Baker BJ (2008) Macroalgal chemical defenses in polar marine communities. In: Amsler CD (ed) Algal chemical ecology. Springer, Berlin, p 91-103

Amsler CD, Iken K, McClintock JB, Baker BJ (2009) Defenses of polar macroalgae against herbivores and biofoulers. Bot Mar 52:535-545

Amsler CD, McClintock JB, Baker BJ (2014) Chemical mediation of mutualistic interactions between macroalgae and mesograzers structure unique coastal communities along the western Antarctic Peninsula. J Phycol 50:1-10

Arnold T, Mealey C, Leahey H, Miller AW, Hall-Spencer JM, Milazzo M, Maers K (2012) Ocean acidification and the loss of phenolic substances in marine plants. PLOS ONE 7:e35107

*Aumack CF, Amsler CD, McClintock JB, Baker BJ (2010) Chemically mediated resistance to mesoherbivory in finely branched macroalgae along the western Antarctic Peninsula. Eur J Phycol 45:19-26

Benítez S, Duarte C, López J, Manríquez PH and others (2016) Ontogenetic variability in the feeding behavior of a marine amphipod in response to ocean acidification. Mar Pollut Bull 112:375-379

Bermúdez R, Feng Y, Roleda MY, Tatters AO and others (2015) Long-term conditioning to elevated $\mathrm{pCO}_{2}$ and warming influences the fatty and amino acid composition of the diatom Cylindrotheca fusiformis. PLOS ONE 10:e0123945

Bradford MM (1976) A rapid and sensitive method for the quantitation of microgram quantities of protein utilizing the principle of protein-dye binding. Anal Biochem 72: 248-254

Brown JH, Gillooly JF, Allen AP, Savage VM, West GB (2004) Response to forum commentary on 'Toward a metabolic theory of ecology'. Ecology 85:1818-1821

Bucolo P, Amsler CD, McClintock JB, Baker BJ (2011) Palatability of the Antarctic rhodophyte Palmaria decipiens (Reinsch) RW Ricker and its endo/epiphyte Elachista antarctica Skottsberg to sympatric amphipods. J Exp Mar Biol Ecol 396:202-206

Chen B, Zou D, Zhu M, Yang Y (2017) Effects of $\mathrm{CO}_{2}$ levels and light intensities on growth and amino acid contents in red seaweed Gracilaria lemaneiformis. Aquacult Res 48:2683-2690

* Clayton MN (1994) Evolution of the Antarctic marine benthic algal flora. J Phycol 30:897-904

Constable AJ, Melbourne-Thomas J, Corney SP, Arrigo KR and others (2014) Climate change and Southern Ocean ecosystems I: how changes in physical habitats directly affect marine biota. Glob Chang Biol 20:3004-3025

Côté IM, Darling ES (2010) Rethinking ecosystem resilience in the face of climate change. PLOS Biol 8:e1000438

Cripps G, Flynn KJ, Lindeque PK (2016) Ocean acidification affects the phyto-zoo plankton trophic transfer efficiency. PLOS ONE 11:e0151739

Cruz-Rivera E, Hay ME (2001) Macroalgal traits and the feeding and fitness of an herbivorous amphipod: the roles of selectivity, mixing, and compensation. Mar Ecol Prog Ser 218:249-266

* Cruz-Rivera E, Hay ME (2003) Prey nutritional quality interacts with chemical defenses to affect consumer feeding and fitness. Ecol Monogr 73:483-506

de la Haye KL, Spicer JI, Widdicombe S, Briffa M (2011) Reduced sea water $\mathrm{pH}$ disrupts resource assessment and decision making in the hermit crab Pagurus bernhardus. Anim Behav 82:495-501

* Díaz-Gil C, Catalán IA, Palmer M, Faulk CK, Fuiman LA (2015) Ocean acidification increases fatty acids levels of larval fish. Biol Lett 11:20150331

*Dickson AG (1990) Standard potential of the reaction: $\mathrm{AgCl}(\mathrm{s})$ $+1 / 2 \mathrm{H}_{2}(\mathrm{~g})$ and the standard acidity constant of the ion $\mathrm{HSO}_{4}$ in synthetic sea water from 273.15 to $318.15 \mathrm{~K}$. J Chem Thermodyn 22:113-127

Dickson AG, Sabine CL, Christian JR (2007) Guide to best practices for ocean $\mathrm{CO}_{2}$ measurements. PICES Spec Publ 3. North Pacific Marine Science Organization, Sidney, BC

* Duarte C, López J, Benítez S, Manríquez PH and others (2016) Ocean acidification induces changes in algal palatability and herbivore feeding behavior and performance. Oecologia 180:453-462

* Ducklow HW, Fraser WR, Meredith MP, Stammerjohn SE and others (2013) West Antarctic Peninsula: An icedependent coastal marine ecosystem in transition. Oceanography (Wash DC) 26:190-203

*Eklöf JS, Havenhand JN, Alsterberg C, Gamfeldt L (2015) Community-level effects of rapid experimental warming and consumer loss outweigh effects of rapid ocean acidification. Oikos 124:1040-1049

*Fabry VJ, McClintock JB, Mathis JT, Grebmeier JM (2009) Ocean acidification at high latitudes: the bellweather. Oceanography (Wash DC) 22:160-171

Fairhead VA, Amsler CD, McClintock JB, Baker BJ (2006) Lack of defense or phlorotannin induction by UV radiation or mesograzers in Desmarestia anceps and D. menziesii (Phaeophyceae). J Phycol 42:1174-1183

Falkenberg LJ, Russell BD, Connell SD (2012) Stability of strong species interactions resist the synergistic effects of local and global pollution in kelp forests. PLOS ONE 7: e33841

Falkenberg LJ, Russell BD, Connell SD (2013) Future herbivory: the indirect effects of enriched $\mathrm{CO}_{2}$ may rival its direct effects. Mar Ecol Prog Ser 492:85-95

Falkenberg LJ, Connell SD, Russell BD (2014) Herbivory mediates the expansion of an algal habitat under nutrient and $\mathrm{CO}_{2}$ enrichment. Mar Ecol Prog Ser 497:87-92

Folch J, Lees M, Stanley GHS (1957) A simple method for the isolation and purification of total lipides from animal tissues. J Biol Chem 226:497-509

Folke C, Carpenter S, Walker B, Scheffer M, Elmqvist T, Gunderson L, Holling CS (2004) Regime shifts, resilience, and biodiversity in ecosystem management. Annu Rev Ecol Evol Syst 35:557-581

Kattuso JP, Magnan A, Billé R, Cheung W and others (2015) Contrasting futures for ocean and society from different anthropogenic $\mathrm{CO}_{2}$ emissions scenarios. Science 349: aac4722

* Gaylord B, Kroeker KJ, Sunday JM, Anderson KM and others (2015) Ocean acidification through the lens of ecological theory. Ecology 96:3-15

*Ghedini G, Russell BD, Connell SD (2015) Trophic compensation reinforces resistance: herbivory absorbs the increasing effects of multiple disturbances. Ecol Lett 18: 182-187

Hoegh-Guldberg O, Bruno JF (2010) The impact of climate change on the world's marine ecosystems. Science 328 : 1523-1528

Huang YM, McClintock JB, Amsler CD, Peters KJ, Baker BJ 
(2006) Feeding rates of common Antarctic gammarid amphipods on ecologically important sympatric macroalgae. J Exp Mar Biol Ecol 329:55-65

*Huang YM, Amsler MO, McClintock JB, Amsler CD, Baker BJ (2007) Patterns of gammaridean amphipod abundance and species composition associated with dominant subtidal macroalgae from the western Antarctic Peninsula. Polar Biol 30:1417-1430

Iken K (2012) Grazers on benthic seaweeds. In: Wiencke C, Bischof K (eds) Seaweed biology. Springer, Berlin, p $157-175$

Iken K, Amsler CD, Amsler MO, McClintock JB, Baker BJ (2009) Field studies on deterrent properties of phlorotannins in Antarctic brown algae. Bot Mar 52:547-557

Iñiguez C, Carmona R, Lorenzo MR, Niell FX, Wiencke C, Gordillo FL (2016) Increased $\mathrm{CO}_{2}$ modifies the carbon balance and the photosynthetic yield of two common Arctic brown seaweeds: Desmarestia aculeata and Alaria esculenta. Polar Biol 39:1979-1991

IPCC (2014) Climate change 2014: impacts, adaptation, and vulnerability. Part A: global and sectoral aspects. Contribution of Working Group II to the Fifth Assessment Report of the Intergovernmental Panel on Climate Change. Cambridge University Press, Cambridge. http://ipcc.ch/ pdf/assessment-report/ar5/wg2/WGIIAR5-FrontMatterA _FINAL.pdf

Johnson VR, Russell BD, Fabricius KE, Brownlee C, HallSpencer JM (2012) Temperate and tropical brown macroalgae thrive, despite decalcification, along natural $\mathrm{CO}_{2}$ gradients. Glob Chang Biol 18:2792-2803

Kaiser S, Brandão S, Brix S, Barnes DA and others (2013) Patterns, processes and vulnerability of Southern Ocean benthos: a decadal leap in knowledge and understanding. Mar Biol 160:2295-2317

Landes A, Zimmer M (2012) Acidification and warming affect both a calcifying predator and prey, but not their interaction. Mar Ecol Prog Ser 450:1-10

Manly BFJ (1993) Comments on design and analysis of multiple-choice feeding-preference experiments. Oecologia 93:149-152

McNeil BI, Matear RJ (2008) Southern Ocean acidification: A tipping point at 450-ppm atmospheric $\mathrm{CO}_{2}$. Proc Natl Acad Sci USA 105:18860-18864

Moran MD (2003) Arguments for rejecting the sequential Bonferroni in ecological studies. Oikos 100:403-405

Nakagawa S (2004) A farewell to Bonferroni: the problems of low statistical power and publication bias. Behav Ecol 15:1044-1045

* Peters KJ, Amsler CD, Amsler MO, McClintock JB, Dunbar RB, Baker BJ (2005) A comparative analysis of the nutritional and elemental composition of macroalgae from the western Antarctic Peninsula. Phycologia 44:453-463

* Peterson CH, Renaud PE (1989) Analysis of feeding preference experiments. Oecologia 80:82-86

Pimm SL (1984) The complexity and stability of ecosystems. Nature 307:321-326

Poore AGB, Graba-Landry A, Favret M, Brennand HS, Byrne M, Dworjanyn SA (2013) Direct and indirect effects of ocean acidification and warming on a marine plant-herbivore interaction. Oecologia 173:1113-1124

Poore AGB, Graham SE, Byrne M, Dworjanyn SA (2016) Effects of ocean warming and lowered $\mathrm{pH}$ on algal growth and palatability to a grazing gastropod. Mar Biol 163:99

Prince JS, LeBlanc WG, Maciá S (2004) Design and analysis of multiple choice feeding preference data. Oecologia 138:1-4

Editorial responsibility: Peter Steinberg,

Sydney, New South Wales, Australia
Ricevuto E, Lorenti M, Patti FP, Scipione MB, Gambi MC (2012) Temporal trends of benthic invertebrate settlement along a gradient of ocean acidification at natural $\mathrm{CO}_{2}$ vents (Tyrrhenian sea). Biol Mar Mediterr 19:49-52

Riebesell U, Fabry VJ, Hansson L, Gattuso JP (eds) (2010) Guide to best practices for ocean acidification research and data reporting. Publications Office of the European Union, Luxembourg

Roleda MY, Hurd CL (2012) Seaweed responses to ocean acidifiation. In: Wiencke C, Bischof K (eds) Seaweed biology. Ecological studies Vol. 219. Springer-Verlag, Berlin, p 407-431

Kossoll D, Bermúdez R, Hauss H, Schulz KG, Riebesell U, Sommer U, Winder M (2012) Ocean acidificationinduced food quality deterioration constrains trophic transfer. PLOS ONE 7:e34737

Rothman KJ (1990) No adjustments are needed for multiple comparisons. Epidemiology 1:43-46

Roy RN, Roy LN, Vogel KM, Porter-Moore C and others (1993) The dissociation constants of carbonic acid in seawater at salinities 5 to 45 and temperatures 0 to $45^{\circ} \mathrm{C}$. Mar Chem 44:249-267

* Schoenrock KM, Schram JB, Amsler CD, McClintock JB, Angus RA (2015) Climate change impacts on overstory Desmarestia spp. from the western Antarctic Peninsula. Mar Biol 162:377-389

* Schram JB, McClintock JB, Amsler CD, Baker BJ (2015a) Impacts of acute elevated seawater temperature on the feeding preferences of an Antarctic amphipod toward chemically deterrent macroalgae. Mar Biol 162:425-433

K Schram JB, Schoenrock KM, McClintock JB, Amsler CD, Angus RA (2015b) Multi-frequency observations of seawater carbonate chemistry on the central coast of the western Antarctic Peninsula. Polar Res 34:25582

Schram JB, Amsler MO, Amsler CD, Schoenrock KM, McClintock JB, Angus RA (2016a) Antarctic crustacean grazer assemblages exhibit resistance following exposure to decreased pH. Mar Biol 163:1-12

Schram JB, Schoenrock KM, McClintock JB, Amsler CD, Angus RA (2016b) Seawater acidification more than warming presents a challenge for two Antarctic macroalgal-associated amphipods. Mar Ecol Prog Ser 554: 81-97

Sotka EE, Giddens H (2009) Seawater temperature alters feeding discrimination by cold-temperate but not subtropical individuals of an ectothermic herbivore. Biol Bull 216:75-84

* Turner J, Maksym T, Phillips T, Marshall GJ, Meredith MP (2013) The impact of changes in sea ice advance on the large winter warming on the western Antarctic Peninsula. Int J Climatol 33:852-861

Turner J, Barrand NE, Bracegirdle TJ, Convey P and others (2014) Antarctic climate change and the environment: an update. Polar Rec (Gr Brit) 50:237-259

Xu Z, Zou D, Gao K (2010) Effects of elevated $\mathrm{CO}_{2}$ and phosphorus supply on growth, photosynthesis and nutrient uptake in the marine macroalga Gracilaria lemaneiformis (Rhodophyta). Bot Mar 53:123-129

Young RM, Schoenrock KM, von Salm JL, Amsler CD, Baker BJ (2015) Structure and function of macroalgal natural products. In: Stengel DB, Connan S (eds) Natural products from marine algae: methods and protocols. Methods Mol Biol 1308:39-73

Zupo V, Maibam C, Buia M, Gambi M and others (2015) Chemoreception of the seagrass Posidonia oceanica by benthic invertebrates is altered by seawater acidification. J Chem Ecol 41:766-779

Submitted: March 16, 2017; Accepted: August 16, 2017

Proofs received from author(s): September 26, 2017 